\title{
SELECTION OF THE RIGHT MARKETPLACE FOR SALE OF ORNAMENTAL PLANTS USING ANALYTICAL HIERARCHY PROCESS (AHP) METHOD
}

\author{
Syarif Hidayat HR ${ }^{1 *}$; Melan Susanti2; Mari Rahmawati ${ }^{3}$ \\ Sistem Informasi ${ }^{1 *}$ ) ; Teknik Informatika ${ }^{2}$ \\ Sekolah Tinggi Manajemen Informatika dan Komputer Nusa Mandiri ${ }^{1,2}$ \\ www.nusamandiri.ac.id ${ }^{1,2}$ \\ shidayathr@gmail.com¹, melan.msu@nusamandiri.ac.id ${ }^{2}$ \\ Sistem Informasi Akuntansi ${ }^{3}$ \\ Universitas Bina Sarana Informatika ${ }^{3}$ \\ www.bsi.ac.id ${ }^{3}$ \\ mari.mrw@bsi.ac.id ${ }^{3}$ \\ (*) Corresponding Author
}

\begin{abstract}
Each marketplace has its market, therefore as a seller who will start an online business, especially those who use the marketplace, they must know which marketplace is right to start their online business according to what category of goods to sell. This research is needed to help business people, in this case, ornamental plant traders, choose the right marketplace for their online business activities. A Decision Support System (DSS) is a computer-based system used to help make decisions from structured and semistructured problems. Analytical Hierarchy Process (AHP) is a method that can be used to select from the specified criteria. This method can simplify the criteria that are considered in making decisions for marketplace selection to be simpler and easier to understand. The results of the study show that the decisions made using the AHP method are very effective, and are expected to help make objective decisions. After processing data and analyzing respondent data, with the criteria for the number of visitors, transaction system, features, and search engine optimization (SEO), it was found that Lazada (0.428) has the highest priority, Tokopedia (0.235) with second priority, Shopee $(0.204)$ with priority third, and Bukalapak (0.133) with the fourth priority
\end{abstract}

Keywords: Marketplace, Decision Support System, AHP, Ornamental Plants.

Intisari- Pada dasarnya tiap marketplace itu memiliki pasarnya masing-masing, oleh sebab itu sebagai penjual yang akan memulai bisnis online, terutama yang menggunakan marketplace harus mengetahui marketplace mana yang tepat untuk memulai bisnisnya secara online yang sesuai dengan kategori barang apa yang akan dijual. Penelitian ini dibutuhkan untuk membantu para pelaku bisnis dalam hal ini para pedagang tanaman hias memilih marketplace yang tepat untuk kegiatan bisnisnya secara online. Sistem Pendukung Keputusan (SPK) merupakan suatu sistem berbasis komputer yang digunakan untuk membantu mengambil keputusan dari masalah-masalah terstruktur maupun semiterstruktur. Analytical Hierarchy Process (AHP) merupakan metode yang dapat digunakan untuk menyeleksi dari kriteria-kriteria yang ditentukan. Metode ini dapat menyederhanakan kriteria yang menjadi pertimbangan pengambilan keputusan untuk pemilihan marketplace menjadi lebih sederhana dan mudah dipahami. Hasil penelitian menunjukan bahwa keputusan yang ditentukan menggunakan metode AHP sangat efektif, diharapkan dapat membantu mengambil keputusan yang bersifat objektif. Setelah melakukan pengolahan data dan analisis data responden, dengan kriteria jumlah pengunjung, sistem transaksi, fitur, dan searc engine optimization (SEO) diperoleh hasil Lazada $(0,428)$ memiliki prioritas tertinggi, Tokopedia $(0,235)$ dengan prioritas kedua, Shopee $(0,204)$ dengan prioritas ketiga, dan Bukalapak $(0,133)$ dengan prioritas keempat.

Kata Kunci: Marketplace, Sistem Pendukung Keputusan, Analytical Hierachy Process, Tanaman Hias.

\section{INTRODUCTION}

The rapid development and advancement of information and communication technology at present activities through online systems is one solution for all of us in the current pandemic era. With advances in technology have an impact on changes in various fields of life have an impact on lifestyle changes, including consumption patterns and ways of selling and shopping for people. In this era, people use information and communication technology to buy or sell goods or services via the 
internet. The Internet connection can easily be accessed on a computer, tablet, or smartphone. The system is defined as a collection or set of elements, components, or variables that are organized, interact with each other, depend on one another, and are integrated (Rahmawati, 2017). In essence, a system is a group of entities (hardware, Brainware, software) that interact, work together, and collaborate to achieve certain goals (Herliana \& Rasyid, 2016).

Sales systems such as using the internet are in demand and are growing rapidly in the community. Many companies use web-based technology as a strategy in the promotion to increase sales. Companies can also promote goods to consumers without being limited by space and time (Suryatri et al., 2019). This also makes it easier for business actors during the current pandemic to market and sell their merchandise. This phenomenon is known as an online business that provides shopping options for people without the need to come directly to the store. There are various types of online businesses that we often hear about, such as e-commerce (Hidayat et al., 2020).

E-commerce is a trade that is done electronically. Where the activity of buying and selling transactions between sellers and buyers is carried out through electronic-based media, what is meant here is through a website that is connected via the internet network (Pratama et al., 2018). The e-commerce business is indeed very promising to be one of the business opportunities for people in Indonesia. One of the most popular and promising e-commerce models for online businesses and one of the effective means to accommodate sellers and buyers in conducting online transactions today is the marketplace (Susilowati \& Negara, 2018). Ornamental plants have recently become a trend among the public, from low prices to even millions. Currently, many people are taking advantage of this phenomenon as their business opportunity. Apart from selling offline, ornamental plant traders have now entered the marketplace a lot (Hidayat et al., 2020).

, This research is related to PT. Asianindo Pratama wants to take advantage of internet technology in its sales which aims to promote and increase turnover. This research was conducted to determine the e-Marketplace that is suitable for use in terms of service quality, system quality, information quality, and vendor quality owned by the e-Marketplace. This research method uses the Analytical Hierarchy Process (AHP) method and uses the Expert Choice Software. From the research results, the most superior criteria are vendor criteria with a weight value of 0.34 , information quality with a weight value of 0.25 , system quality with a weight value of 0.22 , and service quality with a weight value of 0.19 . Meanwhile, the most superior e-Marketplace alternative is Tokopedia with a weight value of 0.48 or $48 \%$, for second place is Shopee with a weight value of 0.34 or $34 \%$ and the third is Bukalapak with a weight value of 0.18 (Suryatri et al., 2019).

In another study, the number of existing platforms raises new problems, namely how to choose the right platform to create an online store. This study aims to implement a decision support system to determine the best alternative from several alternative existing E-Commerce web platforms using the Analytical Hierarchy Process method (AHP) to assist business actors to build their online stores. The criteria for determining the AHP hierarchical structure include ease of use, security, and features of the four most commonly used web marketplace platforms in Indonesia. The assessment data was obtained through distributing questionnaires and then processed and tested using AHP. The final result of the research is an alternative sequence of the E-Commerce web platform according to the assessment of the web programmers. Based on the assessment using AHP, it was found that the order of the e-commerce web platform that got the highest score was wooed commerce with $26.3 \%$, followed by Openchart $24.46 \%$, Prestashop 24.45\%, and the fourth place was Magento with 23.1\%. Based on these results, the application of the AHP method can provide recommendations in decision making to determine the selection of the E-Commerce web platform that best suits the needs of business actors in building their online stores (Hartini, 2020).

Previous research by (Nurmalasari \& Pratama, 2018). In this study, the authors conducted research related to the selection of spare parts suppliers for PT. Transcoal Pacific is a marine strengthening company. Also, by choosing the optimal supplier, the company can get benefits, either directly or indirectly. At this time, the company has identified five potential suppliers which will be chosen the best, namely UD Sinar Rejeki, Mitra Karya Mandiri, CV Prega Lestari, CV Rachmat, and Multijaya. The calculation results in the criteria table show that the quality criteria are the most important in selecting suppliers, with a percentage of $39.50 \%$, the next is the delivery criteria with a value percentage of $20.56 \%$, the next is the price criteria with a value percentage of $18.18 \%$, then the responsibility criteria with a percentage value of $14.66 \%$ and the last service criteria with a percentage value of $7.09 \%$. The order of priority for Supplier Mitra Karya Mandiri (35.99\%), CV Prega Lestari (31.31\%), CV Rachmat (13.34\%), UD Sinar Rejeki (10.12\%) and finally Multi Jaya (9.24\%) ). This study proves that the criteria for price, quality, service, delivery, and 
responsibility affect the selection of suppliers and determine the best supplier. The most influential criterion is the quality criteria which is $39.50 \%$ and the selected supplier is Mitra Karya Mandiri at $35.99 \%$.

In a study conducted by (Ariani, 2017), Promotion is a major component in the business world. This cannot be separated from the role of print media promotion. The selection of promotional media is a multi-criteria problem. In general, several criteria influence it. This study aims to determine the priority for selecting print media using the Analytical Hierarchy Process (AHP) method. Where alternatives and criteria have been determined by the division concerned. There are seven criteria specified, namely quality, price, estimated processing time, control system, service, payment, and delivery. Decisions can take care of based on the results of the respondent's stimuli, namely by giving a questionnaire containing comparisons between criteria and alternatives. And by using Expert Choice tools in data processing with the AHP method. The result of testing the AHP value on the frontline is 0.9976 . Printing 1 got first place.

Supplier is one of the most important parts of a construction services provider company. PT. Nuance Prima Cipta Tangerang is a contracting company that offers construction services. Since the number of suppliers, PT. Nuance Prima Cipta Tangerang difficulty in choosing suppliers with their respective advantages. Therefore, use AHP (Analytical Hierarchy Process) for supplier selection process to make it more objective. Broadly speaking, AHP (Analytical Hierarchy Process) is the process of comparing criteria into alternatives, the greater the value is generated, then the main well to the supplier selected. By using the AHP method obtained the final value for each alternative Lead A 39\%, 12\%, and Supplier B Supplier C 49\% (Handayani \& Darmianti, 2017).

The crime rate in Indonesia is still very high, therefore martial will be very useful when there is something we do not want, Pencak silat Motion Saka is one of the traditional martial arts that originated from Betawi and clean from the shirk. However, the limited number of trainers became an obstacle to its spread. With the decision support systems into a solution that provides support for consideration in the process of appointment of coaches who can be a standard reference in the process of appointment of the coach and facilitate the removal process to produce a new coach with the right to extend the deployment of the martial arts motion Saka. In the research process using the Analytic Hierarchy Process (AHP) where there are three criteria: character thought patterns and the sense that produces the appointment of the chairman as an important alternative (Nugroho \& Hardiyan, 2016).

To achieve mutual success, SPBU always strives continuously improve internal quality to compete with companies engaged in the same field. One effort that has done is to conduct an assessment employee performance to determine the success or failure in performing their duties. The assessment process still done manually, with relative manual data inaccuracies, and implemented using Microsoft Excel application, so it takes a long time, for data processing. In addition, the assessment is subjective and not relevant to the actual situation, so it can not be used as the basic source of decision making. Analytical Hierarchy Process analysis results from Analytical Hierarchy Process stated that the chosen and most appropriate alternative with criterion is Employee A. With AHP result obtained from questionnaires from 5 respondents who gave the answer calculated and got the final result that Employee A is superior to the percentage value of $23 \%$ compared with Employee E of 22\%, Employee C of 20\%, Employee B of 18\%, and Employee D by $17 \%$. Globally the most important factor prioritized in employee performance appraisal is Responsibility with a weighted value of 0.349 or 35\% and Employees most prioritized are Employee A with a score of $23 \%$. The purpose of this study is to provide alternative decisions that can solve existing problems so that decisions are made for the better (Frieyadie, 2018).

Every parent would want to move to the right school. Parents do not want to choose in choosing schools for children. Choosing a good and right school to answer an easy matter, relates to the judgments made to get an appropriate school choice, as well as adding school choices that allow the community both parents and parents. The existence of supporters of this decision can be a solution to assist the community in the school selection process. The Analytical Hierarchy Process (AHP) method is a method that has a hierarchical structure and makes it easy to simplify a problem from complex criteria to various choices that exist so that it can accelerate the decision-making process in school selection. AHP method produces better results as well as those produced based on the ranking order of each alternative. The results of the calculation of the AHP method are related to four criteria which are the benchmarks in conducting school selection, namely, costs, quality of the school, the ultimate goal of the competition, and talents and interests. The final results of data processing and testing methods obtained by Senior High School (SMA) are superior to 0.373 or $37.3 \%$ while Vocational High School (SMK) is 0.370 or $37.0 \%$, Madrasah Aliyah (MA) is 0.257 or $25.7 \%$ (Narti et al., 2019). 
In previous research related to the use of the AHP method, one important factor is the selection of criteria and respondents to get maximum results. From previous research, respondents used more from the customer side. In the research that the authors conducted, respondents were taken, namely, ornamental plant sellers who already have experience selling online through the marketplace. Because the purpose of this writing is to choose the right marketplace for selling ornamental plants, seen from the seller's point of view in the marketplace where they get more optimal and safer sales and transactions.

The purpose of the authors in making this research report is to find out the right marketplace for ornamental plant traders. To find out the priority level of the Shopee, Tokopedia, Bukalapak, and Lazada marketplaces, for the sale of ornamental plants based on the experiences of the sellers. To find out the sale of ornamental plants, it is more appropriate to market it through Shopee, Tokopedia, Bukalapak, or Lazada by using the Analytic Hierarchy Process (AHP) method.

This research is to help ornamental plant sellers market their merchandise online in four marketplaces, namely Shopee, Tokopedia, Bukalapak, and Lazada as alternatives based on criteria such as several visitors, transaction systems, features, and Search Engine Optimization (SEO).

\section{MATERIALS AND METHODS}

\section{Research Methods}

Decision support systems are methods used in computerization that are used to support determinations, assessments, and actions taken in an organization or business. Decision support systems filter and analyze large amounts of data, gathering comprehensive information that can be used to solve problems in decision-making (Hartini, 2020). Broadly speaking, the author divides into three stages in this writing, namely the planning stage, the implementation stage, and the report writing stage. The elaboration of the stages is as follows:

1. The planning stage in this study is as follows:
a. Problem identification and formulation
b. Reference and literature study
c. Hypothesis formulation
d. Determine the research method.

2. The implementation stage, the activities in this stage are as follows:
a. Collecting data by making observations.
b. Collecting data by distributing questionnaires.
c. Data analysis and interpretation of results.
d. Writing conclusions and suggestions.

3. The report writing stage, the activities in this stage are:

a. Writing reports with data compaction (analysis).

b. Re-check the results of the report by taking into account the format and procedures for scientific writing.

In this study, the authors used a closed questionnaire, namely a questionnaire that the answer had been determined by the researcher, the respondents just had to choose and were not allowed to provide other answers so that the respondent's answer was by the research needs. People who became respondents in this questionnaire were ornamental plant sellers at Tokopedia, Shopee, Bukalapak, and Lazada. Then the data obtained will be processed by the author using the Analytical Hierarchy Process (AHP) method. The following is an example of a questionnaire used in this study:

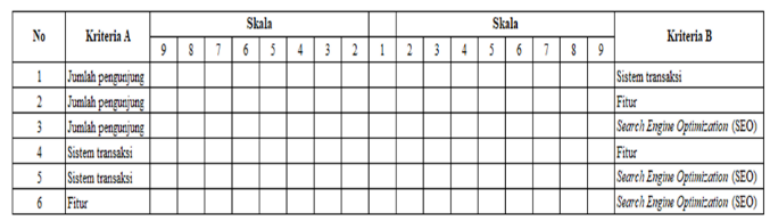

Source: (Hidayat et al., 2020)

Figure 1. Questionnaire (Pairwise Comparison of Criteria)

Figure 1 above, is an example of a paired questionnaire for the main criteria chosen by the author, namely the number of visitors, transaction system, features, and search engine optimization (SEO) criteria.

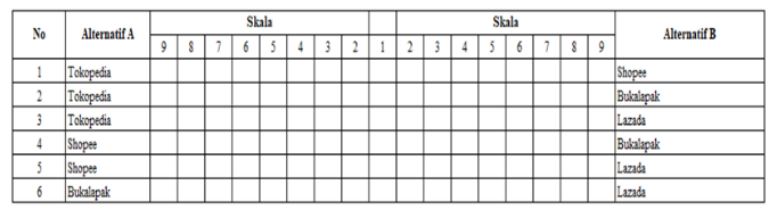

Source: (Hidayat et al., 2020)

Figure 2. Questionnaire (Alternative Pairwise Comparison)

Figure 2 above, is an example of the questionnaire used by the author in this study to compare the selected alternatives, namely Tokopedia, Shopee, Bukalapak, and Lazada.

In this paper, the authors make the population in the research of selecting the right marketplace for ornamental plant sellers, namely ornamental plant traders who have been selling or have experience selling online in the marketplace, in this case, the population in this study is ornamental plant traders in Sasak Panjang, Bogor Regency. The samples used by the author are ornamental plant sellers in Sasak 
Panjang, Bogor Regency, who already have experience selling online in the marketplace. The sample size that is suitable for use in this study is 30 to 500 (Imron, 2019). So for this study, the authors will use 30 respondents who will be given a questionnaire to be sampled in this paper.

\section{Data Collection Techniques}

This method is used because this method is considered more suitable for marketplace selection in selling ornamental plants. In collecting data the author uses several data collection techniques, including:

a. Observation

Collecting data by making direct observations on the object under study, in this case, the researcher makes observations on websites or marketplace applications such as Tokopedia, Shopee, Lazada, and Bukalapak. Researchers also made observations on ornamental plant sellers around Sasak Panjang Village, Bogor Regency.

b. Questionnaires

This study also uses a closed questionnaire, which is a questionnaire that the answer has been determined by the researcher, the respondent only needs to choose and is not allowed to provide other answers so that the respondent's answer is by the research needs. People who became respondents in this questionnaire were ornamental plant sellers in Sasak Panjang Village, Bogor Regency, who had been selling in Tokopedia, Shopee, Bukalapak, and Lazada.

c. Library Research

As a means of supporting the writing of this thesis, the author conducts a literature study using relevant references from the Nusa Mandiri library, library, modules, and materials given in lectures as well as books, journals, and websites that are by the subject matter that the author takes.

The steps for the AHP method are as follows (Marsono, 2020):

1. Defining the problem and determining the desired solution then arranging a hierarchy of the problems at hand.

2. Determine the priority of the elements

a. The first step in determining element priority is making pair comparisons, that is, comparing elements in pairs according to given criteria.

b. The pairwise comparison matrix is filled using numbers to represent the relative importance of one element to another.

3. Synthesis

4. Measure consistency
5. Calculate the consistency index (CI) with the formula:

$\mathrm{CI}=(\lambda$ maks $-\mathrm{n}) /(\mathrm{n}-1)$

Where $\mathrm{n}=$ number of elements

6. Calculate the consistency ratio (CR) with the formula:

$\mathrm{CR}=\mathrm{CI} / \mathrm{IR}$, where:

$\mathrm{CR}=$ Consistency Ratio

$\mathrm{CI}=$ Consistency Index

IR = Index Random Consistency

7. Check hierarchy consistency. If the value is more than $10 \%$, then the judgment data assessment must be corrected. However, if the consistency ratio (CI / IR) is less or equal to 0.1 then the calculation result can be declared correct.

\section{RESULTS AND DISCUSSION}

Complex systems can be understood by breaking them down into supporting elements, arranging elements hierarchically, and combining them or synthesizing them. Defining from general to specific is the goal. In its simplest form, the structure serves to compare objectives, criteria, and alternatives. There are four criteria used in this study, namely the number of visitors, transaction systems, features, search engine optimization (SEO).

The criteria and alternatives for selecting the right marketplace for selling ornamental plants are described in the following hierarchical structure image:

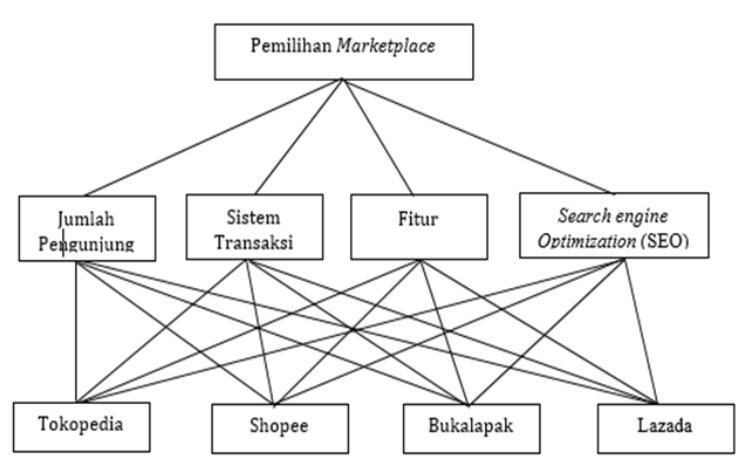

Source: (Hidayat et al., 2020)

Figure 3. Marketplace Selection Hierarchy

Based on Figure 3 the hierarchy above describes problem-solving consisting of goals, criteria, and alternatives.

\section{Data Processing Using Analytical Hierarchy Process (AHP)}

The questionnaire data that has been filled in and collected are summarized into a pairwise comparison table, namely: 
1. Pairwise comparison table between level 1 elements based on main criteria.

2. Pairwise comparison table between level 2 elements based on the criteria for the number of visitors.

3. Pairwise comparison table between level 2 elements based on transaction system criteria.

4. Pairwise comparison table between level 2 elements based on feature criteria.

5. Pairwise comparison table between level 2 elements based on search engine optimization (SEO) criteria.

Then the next step is to find the average ratio for each element by multiplying all the elements of the appeal matrix which are then rooted in rank by the number of respondents. Then we get the average calculation table for each element as follows:

Table 1. Paired Matrix Main Criteria

\begin{tabular}{lcccc}
\hline & $\begin{array}{c}\text { Number } \\
\text { Of } \\
\text { Visitors }\end{array}$ & $\begin{array}{c}\text { Transactio } \\
\text { n System }\end{array}$ & Features & $\begin{array}{c}\text { Search } \\
\text { Engine } \\
\text { Optimizat } \\
\text { ion (SE0) }\end{array}$ \\
\hline Number of Visitors & 1.000 & 0.627 & 1.640 & 1.435 \\
\hline $\begin{array}{l}\text { Transaction } \\
\text { System }\end{array}$ & 1.595 & 1.000 & 3.082 & 1.375 \\
\hline Features & 0.588 & 0.321 & 1.000 & 1.358 \\
\hline $\begin{array}{l}\text { Search Engine } \\
\text { Optimization } \\
\text { (SEO) }\end{array}$ & 0.697 & 0.727 & 0.736 & 1.000 \\
\hline
\end{tabular}

Source: Hidayat (2020)

Based on table 1 above, we can see a comparison of the main criteria that have not been normalized.

Table 2. Comparison of the Number of Visitors Criteria Matrix

\begin{tabular}{lcccc}
\hline & Tokopedia & Shopee & Bukalapak & Lazada \\
\hline Tokopedia & 1.000 & 1.021 & 3.013 & 0.407 \\
\hline Shopee & 0.979 & 1.000 & 1.320 & 0.562 \\
\hline Bukalapak & 0.326 & 0.758 & 1.000 & 0.286 \\
\hline Lazada & 2.454 & 2.027 & 3.496 & 1.000 \\
\hline
\end{tabular}

Source: (Hidayat et al., 2020)

Based on table 2 above, it can be seen that the comparison matrix of the number of visitors criteria for 4 alternatives, namely Tokopedia, Shopee, Bukalapak, and Lazada
Table 3. Comparison of Transaction System Criteria Matrix

\begin{tabular}{lcccc}
\hline & Tokopedia & Shopee & Bukalapak & Lazada \\
\hline Tokopedia & 1.000 & 1.319 & 1.472 & 0.406 \\
\hline Shopee & 0.758 & 1.000 & 1.202 & 0.590 \\
\hline Bukalapak & 0.663 & 0.963 & 1.000 & 0.295 \\
\hline Lazada & 2.463 & 1.695 & 3.384 & 1.000 \\
\hline
\end{tabular}

Source: (Hidayat et al., 2020)

Based on table 3 above, it can be seen that the comparison matrix of the transaction system criteria for 4 alternatives, namely Tokopedia, Shopee, Bukalapak, and Lazada

Table 4. Feature criteria comparison matrix

\begin{tabular}{lcccc}
\hline & Tokopedia & Shopee & Bukalapak & Lazada \\
\hline Tokopedia & 1.000 & 1.509 & 1.687 & 0.509 \\
\hline Shopee & 0.663 & 1.000 & 1.850 & 0.592 \\
\hline Bukalapak & 0.572 & 0.541 & 1.000 & 0.274 \\
\hline Lazada & 1.966 & 1.690 & 3.654 & 1.000 \\
\hline
\end{tabular}

Source: (Hidayat et al., 2020)

Based on table 4 above, it can be seen that the comparison matrix of the feature criteria for 4 alternatives, namely Tokopedia, Shopee, Bukalapak, and Lazada

Table 5. Search Engine Optimization (SEO) Criteria Comparison Matrix

\begin{tabular}{lcccc}
\hline & Tokopedia & Shopee & Bukalapak & Lazada \\
\hline Tokopedia & 1.000 & 1.728 & 2.250 & 0.447 \\
\hline Shopee & 0.579 & 1.000 & 1.318 & 0.900 \\
\hline Bukalapak & 0.424 & 0.758 & 1.000 & 0.351 \\
\hline Lazada & 2.240 & 1.222 & 2.850 & 1.000 \\
\hline
\end{tabular}

Source: (Hidayat et al., 2020)

Based on table 5 above, it can be seen that the comparison matrix of the search engine optimization criteria for 4 alternatives, namely Tokopedia, Shopee, Bukalapak, and Lazada

By dividing the elements in each column by the number of columns concerned, the normalized relative weights are obtained. Eigenvector values are generated from the average relative weights for each row. The results can be obtained in the following table:

Table 6. Hierarchical Factor Matrix for All Normalized Criteria

\begin{tabular}{lccccc}
\hline & $\begin{array}{c}\text { Number Of } \\
\text { Visitors }\end{array}$ & $\begin{array}{c}\text { Transaction } \\
\text { System }\end{array}$ & Features & $\begin{array}{c}\text { Search Engine } \\
\text { Optimization (SEO) }\end{array}$ & Eigen Vector \\
\hline Number of Visitors & 0.258 & 0.234 & 0.254 & 0.278 & 0.256 \\
\hline Transaction System & 0.411 & 0.374 & 0.477 & 0.266 & 0.382 \\
\hline Features & 0.151 & 0.120 & 0.155 & 0.263 & 0.172 \\
\hline $\begin{array}{l}\text { Search Engine } \\
\text { Optimization (SEO) }\end{array}$ & 0.180 & 0.272 & 0.114 & 0.193 & 0.190 \\
\hline Total & 1,000 & 1,000 & 1,000 & 1,000 & 1,000 \\
\hline Source: (Hat & & & & \\
\hline
\end{tabular}

Source: (Hidayat et al., 2020)

Based on table 6 above, it is found that the transaction system has the highest eigenvector value among the other criteria, with a value of 0.382
Table 7. Matrix of Normalized Visitor Criteria

Tokopedia Shopee Bukalapak Lazada Eigen 


\begin{tabular}{llllll}
\hline Tokopedia & 0.210 & 0.212 & 0.341 & 0.181 & 0.236 \\
\hline Shopee & 0.206 & 0.208 & 0.149 & 0.249 & 0.203 \\
\hline Bukalapak & 0.069 & 0.158 & 0.113 & 0.127 & 0.117 \\
\hline Lazada & 0.516 & 0.422 & 0.396 & 0.443 & 0.444 \\
\hline Total & 1,000 & 1,000 & 1,000 & 1,000 & 1,000 \\
\hline Source
\end{tabular}

Source: (Hidayat et al., 2020)

Based on table 7 above, it is found that Lazada has the highest eigenvector value among the other alternatives in the number of visitors criteria, with a value of 0.444

Table 8. Matrix of Normalized Transaction System Criteria

\begin{tabular}{lccccc}
\hline & Tokopedia & Shopee & Bukalapak & Lazada & $\begin{array}{l}\text { Eigen } \\
\text { Vector }\end{array}$ \\
\hline Tokopedia & 0.205 & 0.265 & 0.209 & 0.177 & 0.214 \\
\hline Shopee & 0.155 & 0.201 & 0.170 & 0.258 & 0.196 \\
\hline Bukalapak & 0.136 & 0.194 & 0.142 & 0.129 & 0.150 \\
\hline Lazada & 0.504 & 0.341 & 0.479 & 0.436 & 0.440 \\
\hline Total & 1,000 & 1,000 & 1,000 & 1,000 & 1,000 \\
\hline
\end{tabular}

Source: (Hidayat et al., 2020)

Based on table 8 above, it is found that Lazada has the highest eigenvector value among the other alternatives in the transaction system criteria, with a value of 0.440

Table 9. Matrix of Normalized Feature Criteria

\begin{tabular}{lccccc}
\hline & Tokopedia & Shopee & Bukalapak & Lazada & $\begin{array}{c}\text { Eigen } \\
\text { Vector }\end{array}$ \\
\hline Tokopedia & 0.238 & 0.318 & 0.206 & 0.214 & 0.244 \\
\hline Shopee & 0.158 & 0.211 & 0.226 & 0.249 & 0.211 \\
\hline Bukalapak & 0.136 & 0.114 & 0.122 & 0.115 & 0.122 \\
\hline Lazada & 0.468 & 0.357 & 0.446 & 0.421 & 0.423 \\
\hline Total & 1,000 & 1,000 & 1,000 & 1,000 & 1,000 \\
\hline
\end{tabular}

Source: (Hidayat et al., 2020)

Based on table 9 above, it is found that Lazada has the highest eigenvector value among the other alternatives in the feature criteria, with a value of 0.423

Table 10. Matrix of Normalized Search Engine Optimization (SEO) Criteria

\begin{tabular}{lccccc}
\hline & Tokopedia & Shopee & Bukalapak & Lazada & $\begin{array}{c}\text { Eigen } \\
\text { Vector }\end{array}$ \\
\hline Tokopedia & 0.236 & 0.367 & 0.303 & 0.166 & 0.268 \\
\hline Shopee & 0.136 & 0.212 & 0.178 & 0.334 & 0.215 \\
\hline Bukalapak & 0.100 & 0.161 & 0.135 & 0.130 & 0.132 \\
\hline Lazada & 0.528 & 0.259 & 0.384 & 0.371 & 0.386 \\
\hline Total & 1,000 & 1,000 & 1,000 & 1,000 & 1,000 \\
\hline
\end{tabular}

Source: (Hidayat et al., 2020)

Based on table 10 above, it is found that Lazada has the highest eigenvector value among the other alternatives in the search engine optimization (SEO) criteria, with a value of 0.386

Then the value of the eigenvector is multiplied by the original matrix, resulting in a value for each row, which then divides each value back into the vector concerned. The average value of the results of this division is the maximum principal eigenvalue ( $\lambda$ maks). Then calculate the consistency index (CI) and consistency ratio (CR).

\section{A. Calculation of Main Criteria}

The value of the eigenvector is multiplied by the original matrix, resulting in a value for each row, which is then divided again by the vector concerned. The average value of the results of this division is the maximum principal eigenvalue ( $\lambda$ maks). If CR $<0.1(10 \%)$, it means that the preference of the respondent is consistent, here is the calculation for the main criteria:

\begin{tabular}{|c|c|c|c|c|c|c|}
\hline$[1,000$ & 0,627 & 1,640 & 1,435 & & {$[0,256]$} & {$[1,050]$} \\
\hline 1,595 & 1,000 & 3,082 & 1,375 & $\mathbf{X}$ & 0,382 & 1,582 \\
\hline 0,588 & 0,321 & 1,000 & 1,358 & $\boldsymbol{X}$ & 0,172 & 0,703 \\
\hline$[0,697$ & 0,727 & 0,736 & 1,000 & & {$[0,190]$} & 0,773 \\
\hline$[1,050$ & 0,2 & & 041 & \multirow{4}{*}{\multicolumn{2}{|c|}{$\sum 16,397$}} & \\
\hline 1,582 & 0,3 & & $141{ }_{\Gamma}$ & & & \\
\hline 0,703 & 0,1 & 2 & $\left.081\right|^{2}$ & & & \\
\hline 0,773 & 0,1 & & 073] & & & \\
\hline
\end{tabular}

$\lambda \max =\frac{16,397}{4}=4,099$

$\mathrm{CI}=\frac{(\lambda \max -\mathrm{n})}{n-1}=\frac{(4,099-4)}{4-1}=0,033$

$\mathrm{CR}=\mathrm{CI} / \mathrm{RI}=0,033 / 0,90=0,037$

\section{B. Calculation Criteria for Number of Visitors}

The value of the eigenvector is multiplied by the original matrix, resulting in a value for each row, which is then divided again by the vector concerned. The average value of the results of this division is the maximum principal eigenvalue ( $\lambda$ maks). If CR $<0.1(10 \%)$, it means that the preference of the respondent is consistent, here is the calculation for the number of visitors.

$$
\begin{aligned}
& {\left[\begin{array}{llll}
1,000 & 1,021 & 3,013 & 0,407 \\
0,979 & 1,000 & 1,320 & 0,562 \\
0,326 & 0,758 & 1,000 & 0,286 \\
2,454 & 2,027 & 3,496 & 1,000
\end{array}\right] \times\left[\begin{array}{l}
0,236 \\
0,203 \\
0,117 \\
0,444
\end{array}\right]=\left[\begin{array}{l}
0,976 \\
0,838 \\
0,475 \\
1,843
\end{array}\right]} \\
& {\left[\begin{array}{ll}
0,976 & 0,236
\end{array}\right]\left[\begin{array}{l}
4,132 \\
0,838
\end{array}\right]} \\
& {\left[\begin{array}{lll}
0,838 & : & 0,203 \\
0,475 & & 0,117 \\
1,843 & & 0,444
\end{array}\right]=\left[\begin{array}{l}
4,125 \\
4,071 \\
4,149
\end{array}\right] \sum 16,477} \\
& \lambda \max =\frac{16,477}{4}=4,119 \\
& \mathrm{CI}=\frac{(\lambda \max -\mathrm{n})}{n-1}=\frac{(4,119-4)}{4-1}=0,040 \\
& \mathrm{CR}=\mathrm{CI} / \mathrm{RI}=0,040 / 0,90=0,044
\end{aligned}
$$

\section{Calculation of Transaction System Criteria}

The value of the eigenvector is multiplied by the original matrix, resulting in a value for each row, which is then divided again by the vector concerned. The average value of the results of this division is the maximum principal eigenvalue ( $\lambda$ maks). If CR $<0.1(10 \%)$, it means that the preference of the 
respondent is consistent, here is the calculation for the transaction system:

$$
\begin{aligned}
& {\left[\begin{array}{llll}
1,000 & 1,319 & 1,472 & 0,406 \\
0,758 & 1,000 & 1,202 & 0,590 \\
0,663 & 0,963 & 1,000 & 0,295 \\
2,463 & 1,695 & 3,384 & 1,000
\end{array}\right] \times\left[\begin{array}{l}
0,214 \\
0,196 \\
0,150 \\
0,440
\end{array}\right]=\left[\begin{array}{l}
0,872 \\
0,798 \\
0,611 \\
1,807
\end{array}\right]} \\
& {\left[\begin{array}{lll}
0,872 & & 0,214 \\
0,798 & : & 0,196 \\
0,611 & & 0,150 \\
1,807 & & 0,440
\end{array}\right]=\left[\begin{array}{l}
4,077 \\
4,072 \\
4,072 \\
4,105
\end{array}\right] \sum 16,325} \\
& \lambda \max =\frac{16,325}{4}=4,081 \\
& \mathrm{CI}=\frac{(\lambda \max -\mathrm{n})}{n-1}=\frac{(4,081)-4)}{4-1}=0,027 \\
& \mathrm{CR}=\mathrm{CI} / \mathrm{RI}=0,027 / 0,90=0,030
\end{aligned}
$$

\section{Calculation of Feature Criteria}

The value of the eigenvector is multiplied by the original matrix, resulting in a value for each row, which is then divided again by the vector concerned. The average value of the results of this division is the maximum principal eigenvalue $(\lambda$ maks). If CR $<0.1(10 \%)$, it means that the preference of the respondent is consistent, here is the calculation for the feature:

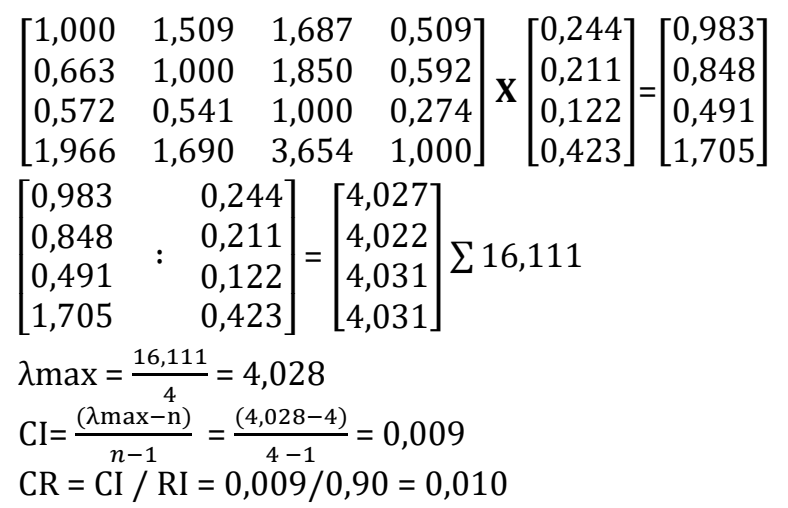

\section{E. Calculation of Search Engine Optimization (SEO) Criteria}

The value of the eigenvector is multiplied by the original matrix, resulting in a value for each row, which is then divided again by the vector concerned. The average value of the results of this division is

\begin{tabular}{|c|c|c|c|c|c|c|}
\hline$[1,000$ & 1,728 & 2,250 & 0,447 & & {$[0,268]$} & {$[1,108]$} \\
\hline 0,579 & 1,000 & 1,318 & 0,900 & $y$ & 0,215 & 0,890 \\
\hline 0,424 & 0,758 & 1,000 & 0,361 & $x$ & 0,132 & 0,544 \\
\hline 2,240 & 1,222 & 2,850 & 1,000 & & {$[0,386$} & 1,623 \\
\hline$[1,108$ & 0,2 & & 347 & \multirow{4}{*}{\multicolumn{2}{|c|}{$\sum 16,618$}} & \\
\hline 0,890 & 0,2 & & $\left.141\right|_{\Gamma}$ & & & \\
\hline 0,544 & 0,1 & & $\left.134\right|^{2}$ & & & \\
\hline 1,623 & 0,3 & & 209 & & & \\
\hline
\end{tabular}
the maximum principal eigenvalue ( $\lambda$ maks). If CR $<0.1(10 \%)$, it means that the preference of the respondent is consistent, here is the calculation for the search engine optimization:

$\lambda \max =\frac{16,618}{4}=4,154$

$\mathrm{CI}=\frac{(\lambda \max -\mathrm{n})}{n-1}=\frac{(4,154-4)}{4-1}=0,051$

$\mathrm{CR}=\mathrm{CI} / \mathrm{RI}=0,051 / 0,90=0,057$

If the value is more than $10 \%$, then the judgment data assessment must be corrected. However, if the consistency ratio (CI / IR) is less or equal to 0.1 then the calculation result can be declared correct. Because CR $<0.1(10 \%)$, it means that the preference of respondents is consistent.

\section{F. Final Calculation Results}

After calculating the data from the results of filling out the questionnaire and then making it into a comparison matrix, from the whole calculation, the following results are obtained:

Table 11. Final Calculation Results

\begin{tabular}{lcccc}
\hline & $\begin{array}{c}\text { Number Of } \\
\text { Visitors }\end{array}$ & $\begin{array}{c}\text { Transactio } \\
\text { n System }\end{array}$ & Features & $\begin{array}{c}\text { Search Engine } \\
\text { Optimization (SEO) }\end{array}$ \\
\hline Tokopedia & 0.236 & 0.214 & 0.244 & 0.268 \\
\hline Shopee & 0.203 & 0.196 & 0.211 & 0.215 \\
\hline Bukalapak & 0.117 & 0.150 & 0.122 & 0.132 \\
\hline Lazada & 0.444 & 0.440 & 0.423 & 0.386 \\
\hline
\end{tabular}

Source: (Hidayat et al., 2020)

\begin{tabular}{ccc}
\hline & $\begin{array}{c}\text { Eigen } \\
\text { Vector }\end{array}$ & $\begin{array}{c}\text { EV } \\
\text { Decision }\end{array}$ \\
\hline 0.256 & 0.235 \\
\hline 0.382 & 0.204 \\
\hline 0.172 & 0.133 \\
\hline 0.190 & 0.428 \\
\hline
\end{tabular}

Based on table 11, the calculation of data from the results of filling out the questionnaire and then being used as a comparison matrix, then from all these calculations the following results are obtained:

a. The combined eigenvector at level 2 criteria (alternative level) is multiplied by the eigenvector at level 1 (the main criterion). b. The result of the multiplication operation is called the decision eigenvector, the decision is determined by the value that has the greatest number.

From the decision eigenvector, it can be seen that:

a. Lazada has the highest priority weight, namely 0.428 .

b. Tokopedia has a second priority weight of 0.235 . 
c. Shopee has a third priority weight of 0.204 .

d. Bukalapak has the lowest priority weight, which is 0.133

If it is depicted in graphic form, it can be seen the percentage number as follows:

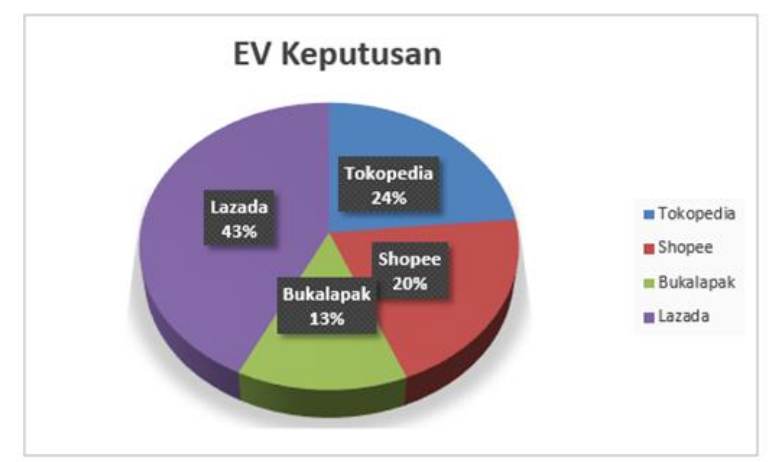

Source: (Hidayat et al., 2020)

Figure 4. Eigenvector Percentage of Decisions Vector

Based on figure 4, it is known that the marketplace selection for selling ornamental plants with the highest percentage is Lazada at $43 \%$ based on the criteria determined by the author.

\section{CONCLUSION}

In the research conducted, it can be concluded that the final results of the calculation of questionnaire data given to 30 respondents, for selecting the right marketplace as a place for ornamental plant businessmen to start their business online according to the criteria for the number of visitors, transaction systems, features, and search engine optimization (SEO) with alternatives to Tokopedia, Shopee, Bukalapak, and Lazada, the final results are Lazada is the marketplace with the highest priority earning a value of 0.428 or $43 \%$. Tokopedia is ranked second with a value of 0.235 or $24 \%$. Shopee is ranked third with a value of 0.204 or $20 \%$. Bukalapak is in the last position with a value of 0.133 or $13 \%$.

\section{REFERENCE}

Ariani. (2017). Sistem Penunjang Dalam Penentuan Prioritas Pemilihan Percetakan Media Promosi Menggunakan Metode AHP. Jurnal Informatika, 4(2), 214-221.

Frieyadie, F. (2018). Metode AHP Sebagai Penunjang Keputusan Untuk Penilaian Kinerja Kerja Karyawan SPBU. Jurnal Techno Nusa Mandiri, 15(1), 63-68. https://doi.org/10.33480/techno.v15i1.60

Handayani, R. irma, \& Darmianti, Y. (2017). Pemilihan Supplier Bahan Baku Bangunan Dengan Metode Analytical Hierarchy Process
(AHP) Pada PT. Cipta Nuansa Prima Tangerang. Jurnal Techno Nusa Mandiri, 14(1), 1-8.

https://doi.org/10.33480/techno.v14i1.176

Hartini, S. (2020). Metode Analytical Hiearchy Process Pada Pemilihan Platform Website ECommerceTerbaik Untuk Membangun Toko Online. 4(2), 134-143.

Herliana, A., \& Rasyid, P. M. (2016). Sistem Informasi Monitoring Pengembangan Software Pada Tahap Development Berbasis Web. Jurnal Informatika, 3(1), 41-50. https://ejournal.bsi.ac.id/ejurnal/index.php/ ji/article/view/281

Hidayat, S., Susanti, M., \& Rahmawati, M. (2020). Laporan Akhir Penelitian: Sistem Pendukung Keputusan Pemilihan Marketplace yang Tepat Untuk Penjualan Tanaman Hias Menggunakan Metode Analytical Hierarchy Process (AHP).

Imron, I. (2019). Analisa Pengaruh Kualitas Produk Terhadap Kepuasan Konsumen Menggunakan Metode Kuantitatif Pada CV. Meubele Berkah Tangerang. Indonesian Journal on Software Engineering (IJSE), 5(1), 19-28. https://doi.org/10.31294/ijse.v5i1.5861

Marsono, M. (2020). Penggunaan Metode Analytical Hierarchy Process (AHP) Dalam Penelitian. In Media.

Narti, N.-, Sriyadi, S., Rahmayani, N., \& Syarif, M. (2019). Pengambilan Keputusan Memilih Sekolah Dengan Metode AHP. Jurnal Informatika, 6(1), 143-150. https://doi.org/10.31311/ji.v6i1.5552

Nugroho, A. N., \& Hardiyan, H. (2016). Decision Support System (Dss) Dalam Pengangkatan Pelatih Pencak Silat Gerak Saka Dengan Metode Analytical Hierarchy Process (Ahp). None, 13(2), 89-95.

Nurmalasari, \& Pratama, A. A. (2018). Sistem Pendukung Keputusan Pemilihan Supplier Menggunakan Metode AHP Pada PT Transcoal Pacific Jakarta. Jurnal Teknik Komputer AMIK BSI (JTK), IV(2), 48-55. https://doi.org/10.31294/jtk.v4i2.3509

Pratama, E. A., Ardiansyah, A., \& Gazy, D. (2018). Pengembangan E-Market Bagi Produk-Produk Kerajinan Dari Bahan Alam Indonesia. Evolusi: Jurnal Sains Dan Manajemen, 6(1). https://doi.org/https://doi.org/10.31294/ev olusi.v6i1.3538

Rahmawati, M. (2017). Bisnis Secara Elektronik. Jurnal Komunikasi, VIII(September), 39-46.

Suryatri, A., Yunita, \& Junaidi, A. (2019). Penerapan Metode Analytical Hierarchy Process Untuk Menentukan Pemilihan E-Marketplace. JSI: Jurnal Sistem Informasi (E-Journal), 11(2), 1835-1844.

https://doi.org/10.36706/jsi.v11i2.9365 
Susilowati, S., \& Negara, M. T. (2018). Implementasi model rapid aplication development (rad). Jurnal TECHNO Nusa Mandiri, 15(1), 25-30. http://ejournal.nusamandiri.ac.id/index.php /techno/article/view/54 